\title{
Effects of Oxides on Tensile and Charpy Impact Properties and Fracture Toughness in Heat Affected Zones of Oxide-Containing API X80 Linepipe Steels
}

\author{
HYO KYUNG SUNG, SEOK SU SOHN, SANG YONG SHIN, KYUNG SHIK OH, \\ and SUNGHAK LEE
}

This study is concerned with effects of complex oxides on acicular ferrite (AF) formation, tensile and Charpy impact properties, and fracture toughness in heat affected zones (HAZs) of oxidecontaining API X80 linepipe steels. Three steels were fabricated by adding $\mathrm{Mg}$ and $\mathrm{O}_{2}$ to form oxides, and various HAZ microstructures were obtained by conducting HAZ simulation tests under different heat inputs. The no. of oxides increased with increasing amount of $\mathrm{Mg}$ and $\mathrm{O}_{2}$, while the volume fraction of AF present in the steel HAZs increased with increasing the no. of oxides. The strengths of the HAZ specimens were generally higher than those of the base metals because of the formation of hard microstructures of bainitic ferrite and granular bainite. When the total Charpy absorbed energy was divided into the fracture initiation and propagation energies, the fracture initiation energy was maintained constant at about $75 \mathrm{~J}$ at room temperature, irrespective of volume fraction of AF. The fracture propagation energy rapidly increased from 75 to $150 \mathrm{~J}$ and saturated when the volume fraction of AF exceeded $30 \mathrm{pct}$. At $253 \mathrm{~K}\left(-20^{\circ} \mathrm{C}\right)$, the total absorbed energy increased with increasing volume fraction of $\mathrm{AF}$, as the cleavage fracture was changed to the ductile fracture when the volume fraction of $\mathrm{AF}$ exceeded 45 pct. Thus, $45 \mathrm{vol}$ pct of AF at least was needed to improve the Charpy impact energy, which could be achieved by forming a no. of oxides. The fracture toughness increased with increasing the no. of oxides because of the increased volume fraction of AF formed around oxides. The fracture toughness did not show a visible correlation with the Charpy absorbed energy at room temperature, because toughness properties obtained from these two toughness testing methods had different significations in view of fracture mechanics.

DOI: $10.1007 / \mathrm{s} 11661-014-2240-2$

(C) The Minerals, Metals \& Materials Society and ASM International 2014

\section{INTRODUCTION}

WELDING is a critical process particularly for large-scale linepipes used for transporting crude oil or natural gas. Welding processes of linepipe steels are generally classified into the seam welding to make pipes from thick steel plates and girth welding to connect pipes. ${ }^{[1-3]}$ During the course of welding, linepipe steels often meet with the problem of low toughness, because heat affected zones (HAZs) are formed in welded regions. According to welding thermal cycles, microstructures such as bainitic ferrite (BF) or martensite

HYO KYUNG SUNG, Postdoctoral Research Associate, and SEOK SU SOHN, Research Assistant, are with the Center for Advanced Aerospace Materials, Pohang University of Science and Technology, Pohang 790-784, Korea. SANG YONG SHIN, Assistant Professor, is with the School of Materials Science and Engineering, University of Ulsan, Ulsan 680-749, Korea. KYUNG SHIK OH, Senior Principal Researcher, is with the Steelmaking Research Group, Technical Research Laboratories, POSCO, Pohang 790-785, Korea. SUNGHAK LEE, Professor, is with the Center for Advanced Aerospace Materials, Pohang University of Science and Technology, and also with the Materials Science and Engineering, Pohang University of Science and Technology. Contact e-mail: shlee@postech. ac.kr

Manuscript submitted September 3, 2012.

Article published online April 12, 2014 having low toughness are readily formed in HAZs, while prior austenite grains are greatly grown. ${ }^{[4]}$ In order to safely use linepipe steels under extreme conditions, thus, the formation of $\mathrm{BF}$ or martensite is prevented or minimized in HAZs, while the formation of acicular ferrite (AF) is promoted.

Recently, oxide metallurgy, in which oxides having excellent high-temperature stability are favorably utilized, has been developed to improve the toughness of the HAZ. ${ }^{[5,6]}$ Oxides act as ferrite nucleation sites at austenite grains during the welding, promote the formation of fine AF, and prevent the formation of coarse bainite or martensite. ${ }^{[7,8]}$ Alloying elements such as $\mathrm{Mg}$, $\mathrm{Ti}$, and Al work effectively for oxide formation, and oxides formed by combining these alloying elements act as nucleation sites for fine AF during the austeniteferrite transformation. ${ }^{[9-12]}$ Larger size and no. of oxides are more effective for the formation of AF ${ }^{[13,14]}$ Since welding thermal cycles and heat inputs greatly affect the formation of AF, various welding methods such as shielded metal arc welding and gas metal arc welding have been developed for reducing heat inputs and increasing welding speeds. ${ }^{[14,15]}$ Thus, correlation studies between the size and no. of oxides, formation of AF, welding thermal cycles, and Charpy impact properties in oxide-containing steel HAZs should be understood to 
improve the HAZ toughness and to achieve appropriate welding conditions.

Though the oxide metallurgy is generally accepted for the toughness improvement, reasons why the toughness is affected by toughness testing conditions including specimen dimension and loading rate, microstructure, and tensile properties have not been sufficiently verified yet. The absorbed energy obtained from the Charpy impact test is generally used to evaluate the toughness but should be understood and related with the fracture toughness measured in a cracked body on the basis of fracture mechanics. Particularly in the quasi-static fracture toughness measurement, oxides can deteriorate the fracture toughness as they work as initiation sites of cracks or voids, while they act as nucleation sites for AF and beneficially enhance the Charpy impact energy. ${ }^{[16]}$ Therefore, systematic studies on mechanisms of toughness improvement in relation with microstructural modification including formation of oxides and $\mathrm{AF}$ under dynamic or quasi-static loading condition in a notched body or a cracked body are essentially needed.

This study aimed at improving toughness properties in the HAZ of API X80 grade linepipe steels by applying the oxide metallurgy. Oxides were formed by adding $\mathrm{Mg}$ and $\mathrm{O}_{2}$ to the steels, and their nos. were controlled by varying amount of $\mathrm{Mg}$ and $\mathrm{O}_{2}$. Various $\mathrm{HAZ}$ microstructures were obtained by conducting HAZ simulation tests under different heat inputs, and their Charpy impact properties and fracture toughness were examined in order to provide guidelines for the improved HAZ toughness. Based on the results of microstructural modification and toughness properties, mechanisms of toughness improvement in oxide-containing linepipe steels were clarified.

\section{EXPERIMENTAL}

\section{A. API X80 Linepipe Steels}

The steels used in this study were API X80 grade linepipe steels [minimum yield strength level: $552 \mathrm{MPa}$ (80 ksi)], and their chemical compositions are shown in Table I. Three API X80 linepipe steels having different the size and no. of oxides were made by varying the amount of $\mathrm{Mg}$ and $\mathrm{O}_{2}$. For convenience, the three steels are referred to as "M1," "M4," and "O4" according to the amount of $\mathrm{Mg}$ and $\mathrm{O}_{2}$. The "M1" steel, a conventional API X80 linepipe steel, contains a considerable amount of $\mathrm{Al}$ and Ti for removing oxygen and nitrogen during the steel-making process and for controlling the austenite grain size during the reheating prior to the rolling, together with a small amount of $\mathrm{O}_{2}$. In the "M4" steel, $\mathrm{Mg}$ is additionally added to form a larger amount of oxides than in the M1 steel, while $\mathrm{O}_{2}$ can be retained, and the $\mathrm{Al}$ content is reduced for retaining $\mathrm{O}_{2}$ and for forming oxides. ${ }^{[17]}$ The "O4" steel contains higher $\mathrm{O}_{2}$ than the M4 steel to form more oxides. An overall grain refinement effect was expected by rolling with a high-rolling reduction ratio of 75 pct in the nonrecrystallized region of austenite after austenitization at $1393 \mathrm{~K}\left(1120^{\circ} \mathrm{C}\right) .{ }^{[18,19]}$ Rolling was finished at $1093 \mathrm{~K}$ $\left(820^{\circ} \mathrm{C}\right)$ in the austenite region above $\mathrm{Ar}_{3}$, and the final thickness was $60 \mathrm{~mm}$. After the finish rolling, the steels were rapidly cooled from $1023 \mathrm{~K}\left(750{ }^{\circ} \mathrm{C}\right)$ to finish cooling temperature of $773 \mathrm{~K}\left(500{ }^{\circ} \mathrm{C}\right)$ at a cooling rate of $24 \mathrm{~K}\left(24^{\circ} \mathrm{C}\right) / \mathrm{s}$ and then were cooled in the air to room temperature. The rolling process took place in laboratory rolling mills in POSCO.

\section{B. Weld Thermal Cycle Simulation Test}

Weld thermal cycle simulation tests were conducted by a metal thermal cycle simulator (MTCS, model: Thermorestor-W, Fuji Electronic Industrial Co., Tokyo, Japan). The thermal cycle of the weld simulation was characterized by the peak temperature and the cooling time from $1073 \mathrm{~K}\left(800^{\circ} \mathrm{C}\right)$ to $773 \mathrm{~K}\left(500{ }^{\circ} \mathrm{C}\right)\left(\Delta t_{1073-773}\right)$ as shown in Figure 1. The coarse-grained HAZ near the welded fusion line was considered as a most brittle zone among HAZs. After reaching the peak temperature of $1673 \mathrm{~K}\left(1400{ }^{\circ} \mathrm{C}\right)$ and holding for 5 seconds, the specimens were cooled down to $1073 \mathrm{~K}\left(800^{\circ} \mathrm{C}\right)$ at a rate of $24 \mathrm{~K}\left(24^{\circ} \mathrm{C}\right) / \mathrm{s}$ before cooling down with $\Delta t_{1073-773}$ of 18 and 30 seconds. The cooling times of 18 and 30 seconds are approximately equivalent to those of a submerged

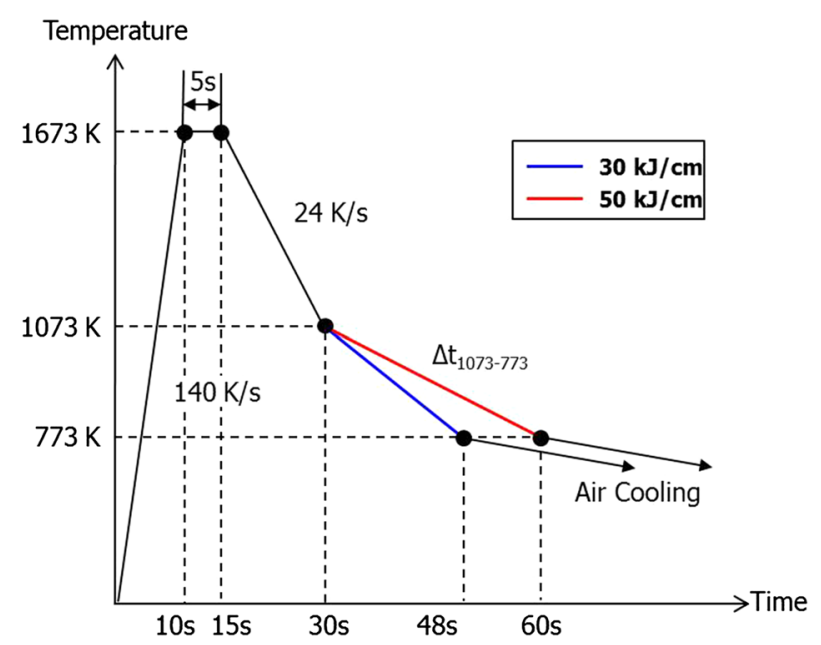

Fig. 1-Schematic diagram of weld thermal cycles of the API X80 linepipe steels.

Table I. Chemical Compositions of the API X80 Linepipe Steels (wt pct)

\begin{tabular}{lccccccccccc}
\hline Steel & $\mathrm{C}$ & $\mathrm{Si}$ & $\mathrm{Mn}$ & $\mathrm{P}+\mathrm{S}$ & $\mathrm{Ni}+\mathrm{Mo}+\mathrm{Cu}$ & $\mathrm{Al}$ & $\mathrm{Nb}$ & $\mathrm{Ti}$ & $\mathrm{Ca}$ & $\mathrm{Mg}$ & $\mathrm{O}_{2}$ \\
\hline $\mathrm{M} 1$ & 0.07 & 0.2 & 1.9 & $<0.004$ & 0.5 & 0.02 & 0.04 & 0.02 & 0.001 & 0.001 & 0.002 \\
M4 & & & & & & 0.01 & & & & 0.004 & 0.002 \\
O4 & & & & & & 0.01 & & & & 0.001 & 0.004 \\
\hline
\end{tabular}


arc welding or electric resistance welding with heat inputs of 30 and $50 \mathrm{~kJ} / \mathrm{cm}$, respectively. ${ }^{[10,20]}$

\section{Microstructural Analysis}

The steels were polished and etched in a 2 pct nital solution, and microstructures of longitudinal-transverse $(L-T)$ planes were observed by a scanning electron microscope (SEM, model: S-4300E, Hitachi, Tokyo, Japan, resolution: $0.2 \mu \mathrm{m}$ ). The size and no. of oxides were quantitatively analyzed from SEM micrographs by an image analyzer. Very fine oxides, which cannot be observed by an SEM, were examined by a transmission electron microscope (TEM, model: JEM-2200FS, Jeol, Japan) operated at an acceleration voltage of $200 \mathrm{kV}$ after carbon extraction replicas were prepared, and their chemical compositions were analyzed by energy dispersive spectroscopy (EDS) installed in the TEM. Electron back-scatter diffraction (EBSD) analysis (resolution; $0.2 \mu \mathrm{m}$ ) was conducted to measure the effective grain size by a field emission scanning electron microscope (FE-SEM, model: S-4300SE, Hitachi, Japan). ${ }^{[21]}$ The data were then interpreted by orientation imaging microscopy analysis software provided by TexSEM Laboratories, Inc.

\section{Tensile, Charpy Impact, and Fracture Toughness Tests}

In the base metal, cylinder-type tensile specimens having a gage diameter of $6 \mathrm{~mm}$ and a gage length of $30 \mathrm{~mm}$ were prepared in the transverse direction and were tested at room temperature at a strain rate of $10^{-3} / \mathrm{s}$ by a universal testing machine (model: 5582, Instron, MA, USA) of $100 \mathrm{kN}$ capacity. ${ }^{[22]}$ In order to determine tensile properties of the simulated HAZ, tension tests were performed after thermal simulation treatments by the MTCS. Plate-type tensile specimens having a gage length of $10 \mathrm{~mm}$, a gage width of $2 \mathrm{~mm}$, and a gage thickness of $2.5 \mathrm{~mm}$ were prepared in the transverse direction. The thermally simulated zone of the MTCS was approximately 10-mm long, and this ensured uniformity along the gage length of all the tensile specimens. The specimens were pulled at room temperature at the same strain rate $\left(10^{-3} / \mathrm{s}\right)$ and testing machine as the base metal.

Charpy impact tests were performed on standard Charpy V-notch specimens [size: $10 \times 10 \times 55 \mathrm{~mm}$, orientation: transverse-longitudinal $(T-L)]$ of the base metal and simulated HAZ at room temperature and $253 \mathrm{~K}\left(-20{ }^{\circ} \mathrm{C}\right)$ by an instrumented Charpy impact tester (model: Kawasaki FS 10N, JT Tohsi, Tokyo, Japan) of $800 \mathrm{~J}$ capacity. ${ }^{[23]}$ Load-displacement curves were obtained from the instrumented Charpy system. From these curves, fracture initiation energy and fracture propagation energy were obtained by measuring the areas below the curve on the basis of the peak load. ${ }^{[24]}$ In general, the fracture propagation energy can be evaluated to be the post-peak energy. ${ }^{[24]}$

Fracture toughness was analyzed in accordance with the ASTM E1921 standard test method. ${ }^{[25]}$ Three-point bending tests were conducted on pre-cracked Charpy $\mathrm{V}$-notch $(\mathrm{PCVN})$ specimens $(10 \times 10 \times 55 \mathrm{~mm})$ with the $T-L$ orientation whose initial crack length was about $5 \mathrm{~mm}$ after thermal simulation treatments by the MTCS. Fatigue pre-cracking was made under a stress ratio, $R$, controlled within the range of $0.01<R<0.1$. The test temperature was fixed at room temperature and $253 \mathrm{~K}\left(-20^{\circ} \mathrm{C}\right)$, and was controlled within $\pm 0.5 \mathrm{~K}$ $\left( \pm 0.5^{\circ} \mathrm{C}\right)$ by liquid nitrogen in a low-temperature chamber filled with ethanol. Load was applied to a PCVN specimen at a displacement loading speed of $1 \mathrm{~mm} / \mathrm{min}$ in order to obtain $J_{c}$, which was then converted to $K_{J_{c}}$ by the following equation:

$$
K_{J_{c}}=\sqrt{J_{c} \cdot E /\left(1-v^{2}\right)},
$$

where $E$ is elastic modulus. The measured $K_{J_{c}}$ was used after checking if it met the following condition:

$$
K_{J_{c}} \leq\left\{E b_{o} \sigma_{\mathrm{ys}} / 30\left(1-v^{2}\right)\right\}^{1 / 2}
$$

where $b_{o}$ and $\sigma_{\mathrm{ys}}$ are initial ligament and yield strength at the test temperature, respectively.

\section{RESULTS}

\section{A. Microstructure of API X80 Linepipe Steels}

Figures 2(a) through (c) show SEM micrographs of the M1, M4, and O4 steels. Various microstructures are marked in the micrographs, and their volume fractions are measured as shown in Table II. All the steels are composed of quasi-polygonal ferrite (QPF), AF, and secondary phases of martensite-austenite (MA) constituent. ${ }^{[26-28]}$ In terms of the shape and characteristics of microstructures, QPF, transformed at the lower temperature than polygonal ferrite, has an irregular grain boundary. AF is generally characterized by fine grain size, irregular-shape, and alignment in arbitrary directions. AF can be grouped into packets having the same orientation between neighboring laths and is known as an excellent microstructure with good combination of strength and toughness. Each microstructure is classified into these morphological categories in the present study. All the steels have similar microstructures composed of AF, together with a small amount of QPF and a few MAs (Table II). The volume fraction of MA ranges 2 to 4 pct.

A TEM micrograph, together with EDS spectrum, of an oxide present in the M4 steel is representatively shown in Figure 3. The EDS spectrum indicates that the oxides are complex oxides, because peaks of $\mathrm{Mg}, \mathrm{Ti}, \mathrm{Nb}$, $\mathrm{Ni}$, and $\mathrm{O}$ are observed. The size and no. of oxides were measured from SEM micrographs, because a no. of very fine oxides are populated in TEM micrographs, and the data are summarized in Table III. Here in the quantitative analysis data, very fine (smaller than $0.1 \mu \mathrm{m}$ ) oxides found in TEM micrographs are excluded. The volume fraction of oxides cannot be measured because of their very fine size. The average oxide size is relatively similar in the range of 0.9 to $1.4 \mu \mathrm{m}$, whereas the no. of oxides is varied in the steels. The total no. of oxides increases in the order of the M1, M4, and O4 steels (in the order of total amount of $\mathrm{Mg}$ and $\mathrm{O}_{2}$ ). Particularly in 

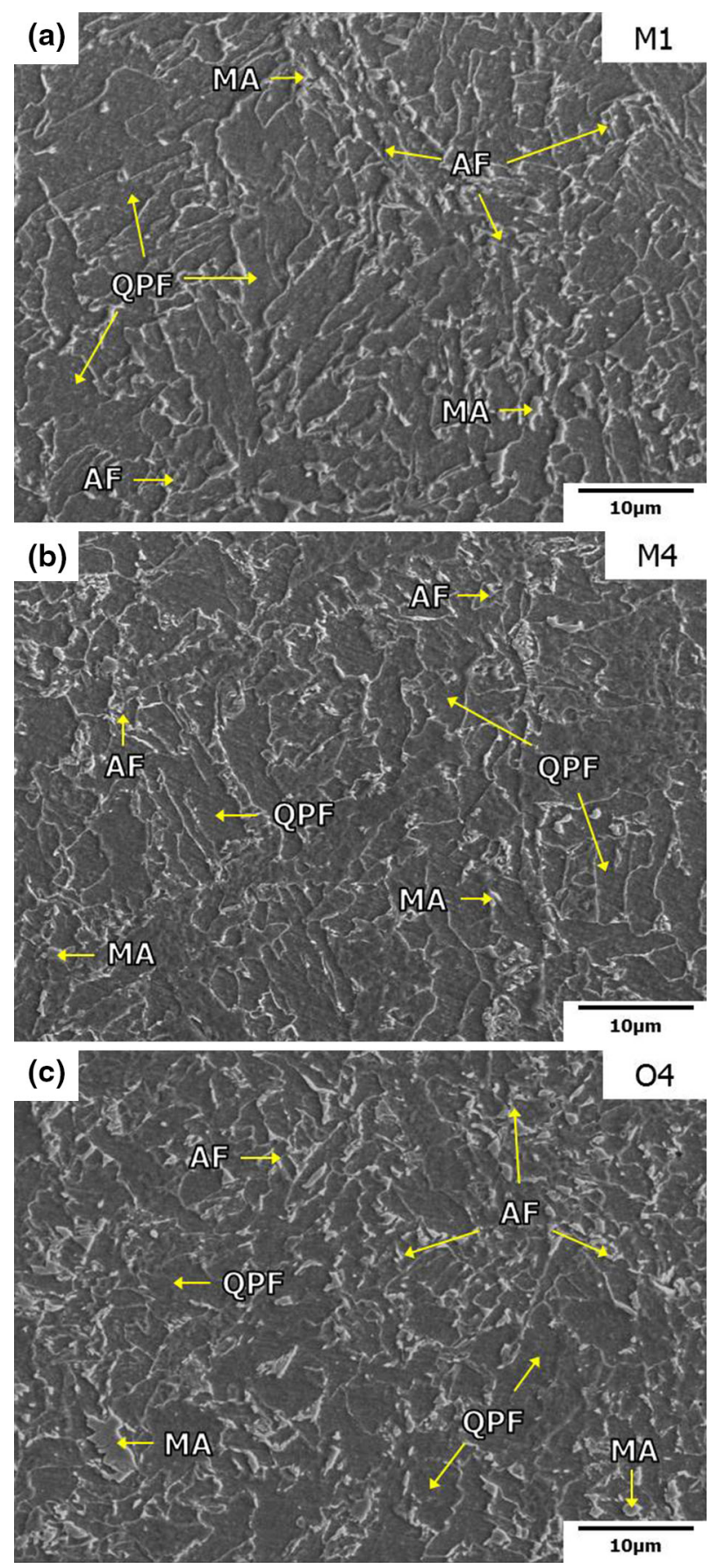

Fig. 2-SEM micrographs ( $L-T$ plane) of (a) M1, (b) M4, and (c) O4 steels. Nital etched.

the $\mathrm{O} 4$ steel, oxides are twice more populated than in the M1 steel.

\section{B. Tensile and Charpy Impact Properties of API X80 Linepipe Steels}

Table IV presents the tensile test results such as yield strength, ultimate tensile strength, and elongation. The yield strength of the M1 steel is higher than that of the M4 and O4 steels. The O4 steel does not satisfy the yield strength level of API X80 linepipe steel grade
Table II. Volume Fractions of Acicular Ferrite (AF), Quasi-Polygonal Ferrite (QPF), and Martensite-Austenite (MA) Constituent Present in the API X80 Linepipe Steels

\begin{tabular}{lccc}
\hline & $\begin{array}{c}\text { Acicular } \\
\text { Ferrite } \\
\text { Steel }\end{array}$ & $\begin{array}{c}\text { Quasi- } \\
\text { Polygonal } \\
\text { Ferrite (pct) }\end{array}$ & $\begin{array}{c}\text { Martensite- } \\
\text { Austenite } \\
\text { Constituent (pct) }\end{array}$ \\
\hline M1 & bal. & $17 \pm 3.9$ & $2 \pm 1.0$ \\
M4 & & $19 \pm 6.8$ & $3 \pm 0.3$ \\
O4 & & $11 \pm 2.0$ & $4 \pm 1.1$ \\
\hline
\end{tabular}

(552 MPa), although it has higher ultimate tensile strength and elongation than the other steels. It shows the lowest yield ratio, because mobile dislocations are well generated by many oxides (Table III). ${ }^{[29]}$

Table IV also lists the Charpy absorbed energy data at room temperature and $253 \mathrm{~K}\left(-20{ }^{\circ} \mathrm{C}\right)$. The absorbed energies of the M1 steel is 327 and $342 \mathrm{~J}$ at $298 \mathrm{~K}$ $\left(25^{\circ} \mathrm{C}\right)$ and $253 \mathrm{~K}\left(-20^{\circ} \mathrm{C}\right)$, respectively, which show excellent impact properties even at low temperatures. The absorbed energy tends to decrease in the order of the M1, M4, and $\mathrm{O} 4$ steels at each test temperature. The O4 steel has relatively low energies, because it contains a large amount of secondary phases having low toughness (Table III).

\section{Microstructure of Simulated HAZ of API X80 Linepipe Steels}

Figures 4(a) through (f) are SEM micrographs of the three steels after the weld simulation test with heat inputs of 30 and $50 \mathrm{~kJ} / \mathrm{cm}$. For convenience, the simulated HAZ specimens are referred to as "M1-30," "M4-30," “O4-30," "M1-50," “M4-50," and 'O4-60," according to steels and heat inputs of 30 and $50 \mathrm{~kJ} / \mathrm{cm}$. The steel HAZ specimens are composed of BF, AF, granular bainite $(\mathrm{GB})$, and $\mathrm{MA}$ according to rapid heating and cooling. BF, AF, and GB are classified by following morphological standards. ${ }^{[14]} \mathrm{BF}$ has welldeveloped laths formed from austenite grain boundaries. ${ }^{[14,26]}$ Its strength is quite high because of high dislocation density inside grains, but its toughness is low. The AF in the HAZ is different from the AF in the base metal. The grain size of AF which is nucleated from the oxides is very fine (under $1 \mu \mathrm{m}$ ), because the cooling rate of HAZ process is faster than that of rolling process. ${ }^{[13,14]} \mathrm{GB}$ contains equiaxed MA and has welldeveloped sub-structures inside.

In all the HAZ specimens, lath-type BFs are mainly formed, and their volume fraction increases with increasing heat input, while the volume fractions of AF and MA decrease because of the decrease in cooling rate. The volume fraction of $\mathrm{BF}, \mathrm{AF}, \mathrm{GB}$, and $\mathrm{MA}$, and the prior austenite grain size (AGS) were measured from SEM micrographs by an image analyzer, and the results are shown in Table $\mathrm{V}$. The volume fraction of $\mathrm{BF}$ decreases in the order of the M1, M4, and O4 steel specimens, whereas the volume fraction of AF shows the opposite trend of BF. The AGS of all the HAZ specimens is similar in the range of 60 to $80 \mu \mathrm{m}$, while the AGS slightly increases in the order of the M1, M4, and $\mathrm{O} 4$ steel HAZ specimens. 

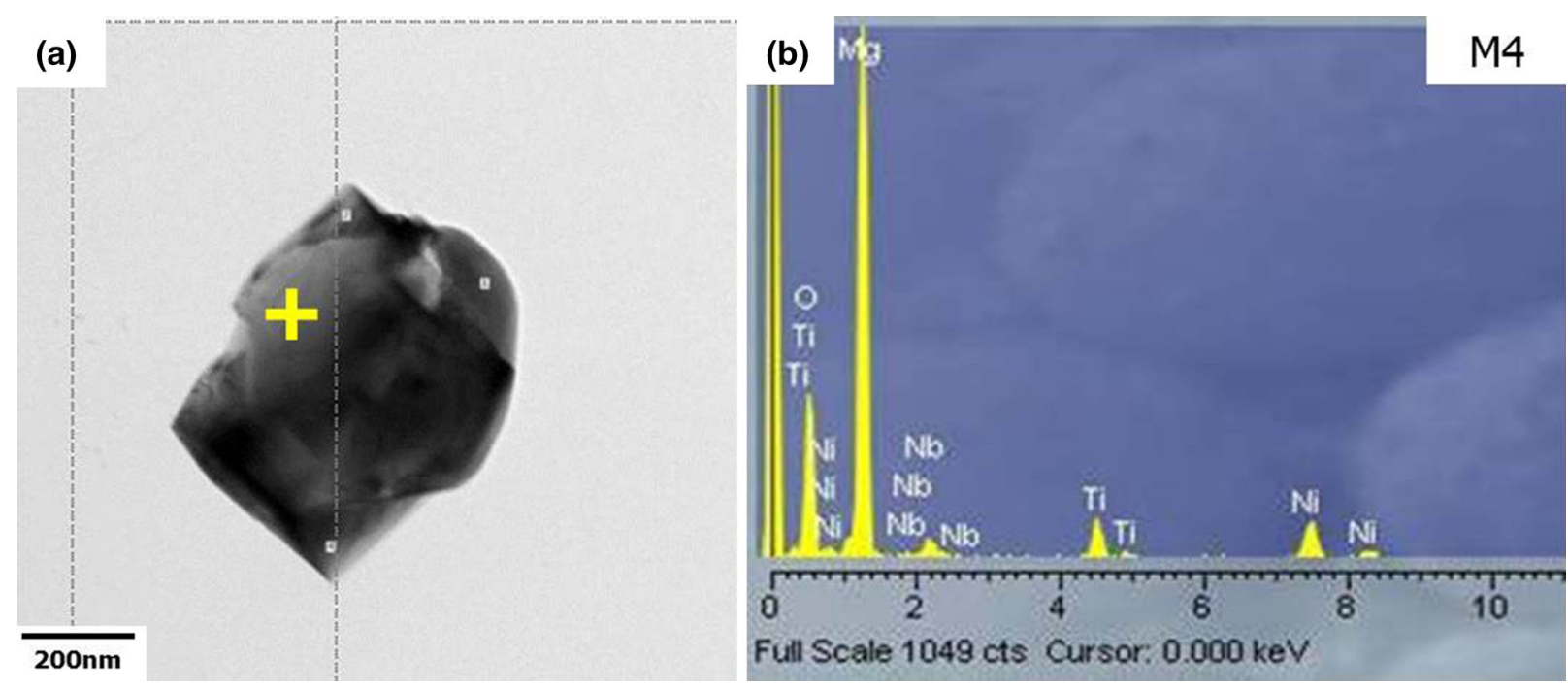

Fig. 3- (a) TEM micrograph and (b) EDS spectrum of a complex oxide present in the M4 steel.

Table III. Quantitative Analysis Data Obtained from the Image Analysis of Complex Oxides Present in the API X80 Linepipe Steels

\begin{tabular}{|c|c|c|c|c|}
\hline \multirow[b]{2}{*}{ Steel } & \multirow[b]{2}{*}{ Average Oxide Size $(\mu \mathrm{m})$} & \multicolumn{3}{|c|}{ No. of Oxides $\left(\mathrm{ea} / \mathrm{mm}^{2}\right)^{*}$} \\
\hline & & $<0.5 \mu \mathrm{m}$ & 0.5 to $5 \mu \mathrm{m}$ & Total \\
\hline M1 & $1.03 \pm 0.57$ & $57.9 \pm 1.6$ & $17.6 \pm 1.2$ & $75.5 \pm 1.1$ \\
\hline M4 & $1.37 \pm 0.70$ & $74.1 \pm 2.1$ & $29.0 \pm 2.9$ & $103.0 \pm 2.0$ \\
\hline $\mathrm{O} 4$ & $0.87 \pm 0.49$ & $100.2 \pm 4.1$ & $44.2 \pm 2.5$ & $144.4 \pm 2.6$ \\
\hline
\end{tabular}

Table IV. Room-Temperature Tensile Properties and Charpy Impact Properties Tested at Room Temperature and $253 \mathrm{~K}$ $\left(-20^{\circ} \mathrm{C}\right)$ of the API X80 Linepipe Steels

\begin{tabular}{lccccc}
\hline & & & & \multicolumn{2}{c}{ Charpy Absorbed Energy $(\mathrm{J})$} \\
\cline { 3 - 6 } Steel & $\begin{array}{c}\text { Yield Strength } \\
(\mathrm{MPa})\end{array}$ & $\begin{array}{c}\text { Ultimate Tensile } \\
\text { Strength }(\mathrm{MPa})\end{array}$ & Elongation $(\mathrm{pct})$ & Room Temperature & $253 \mathrm{~K}\left(-20{ }^{\circ} \mathrm{C}\right)$ \\
\hline M1 & $597 \pm 7$ & $698 \pm 8$ & $19 \pm 1.1$ & $327 \pm 6.2$ & $342 \pm 5.7$ \\
M4 & $562 \pm 5$ & $685 \pm 8$ & $20 \pm 0.8$ & $320 \pm 0.7$ & $325 \pm 6.2$ \\
O4 & $530 \pm 7$ & $711 \pm 10$ & $23 \pm 1.5$ & $259 \pm 2.3$ & $299 \pm 1.0$ \\
\hline
\end{tabular}

The EBSD analysis was conducted on the HAZ specimens, and the results of the M1-50 and M4-30 specimens are shown in Figures 5(a) and (b). Inverse pole figure (IPF) maps can be represented in different colors, depending on the orientation of each point. The boundaries between grains having different orientations of $15 \mathrm{deg}$ or higher are high-angle boundaries, and these grains are generally considered to be effective grains. ${ }^{[30]}$ The measurement data of the effective grain size are shown in Table V. The grain size of the M1-50 specimen is smaller $(49 \mu \mathrm{m})$ than that of the M4-30 specimen $(28 \mu \mathrm{m})$. The coarse grain size in the M1-50 specimen is caused by the containment of many coarse BF and GB. The effective grain size decreases in the order of the M1, M4, and O4 steel HAZ specimens, as the volume fraction of AF whose grains are refined increases. The 30 -series specimens (heat input: $30 \mathrm{~kJ} / \mathrm{cm}$ ) have the smaller effective grain size than the 50 -series specimens (heat input: $50 \mathrm{~kJ} / \mathrm{cm}$ ), because the former contains a higher volume fraction of AF whose grain size is fine. The effective grain size is two or three times smaller than the AGS but does not seem to have a relation with the AGS.

\section{Tensile and Charpy Impact Properties of Simulated HAZ of API X80 Linepipe Steels}

The room-temperature tensile test data of the HAZ specimens are listed in Table VI. The strengths of the HAZ specimens are generally higher than those of the 

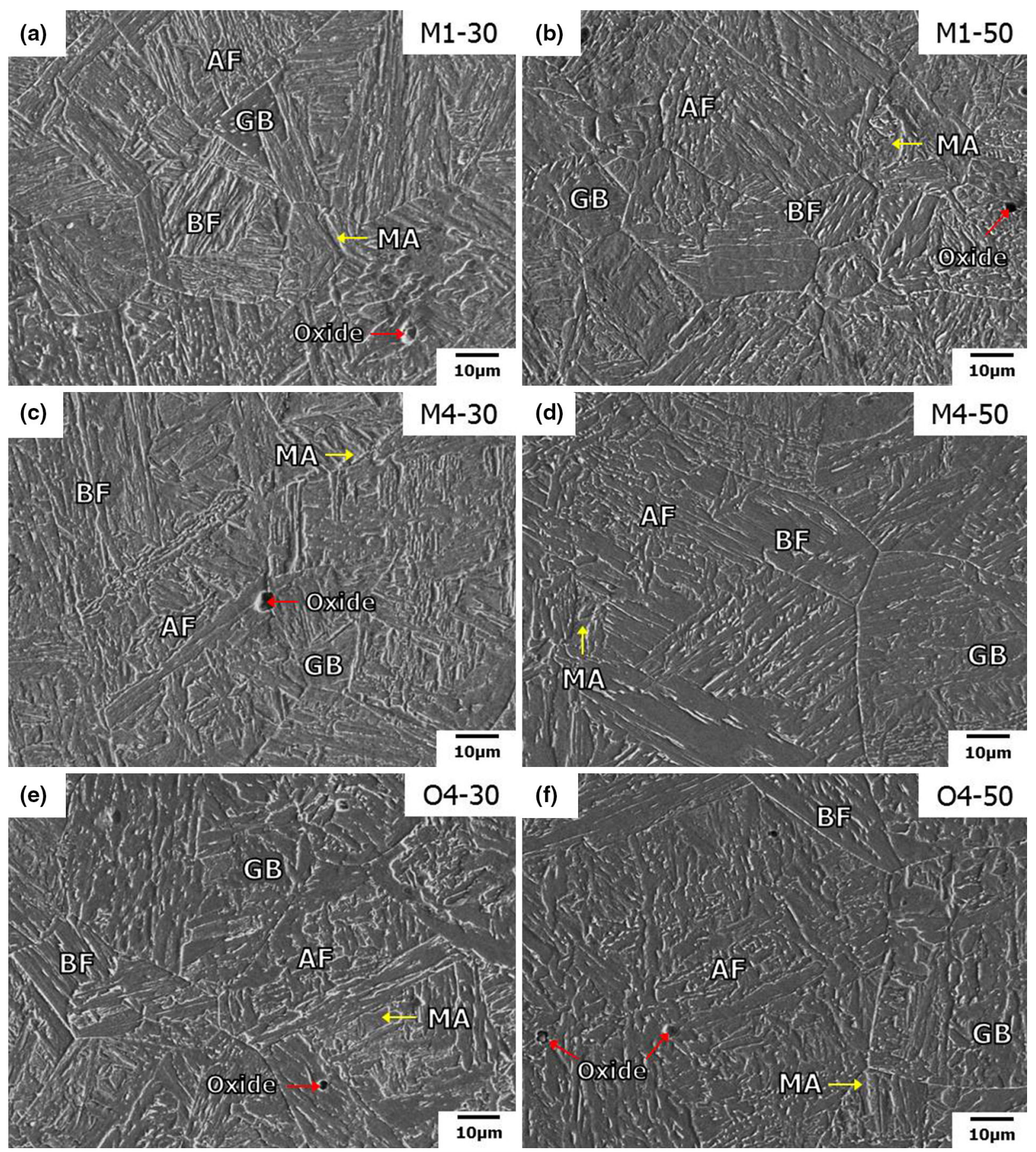

Fig. 4-SEM micrographs of the (a) M1-30, (b) M1-50, (c) M4-30, (d) M4-50, (e) O4-30, and ( $f$ ) O4-50 specimens after the HAZ simulation test (heat input: 30 and $50 \mathrm{~kJ} / \mathrm{cm}$ ). Nital etched.

base metals (Table IV) because of the formation of hard microstructures of BF, GB, and MA. Particularly in the M1-50 specimen, the strengths are the highest because of the highest volume fraction of BF (Table V). The 30series specimens have the lower strengths but the higher elongation than the 50-series specimens because of the lower volume fraction of $\mathrm{BF}$ nucleated in austenite grains at a low degree of supercooling.

Load-displacement curves of the HAZ specimens obtained from the instrumented Charpy system at
$253 \mathrm{~K}\left(-20^{\circ} \mathrm{C}\right)$ are shown in Figures 6(a) through (f). Here, the total absorbed energy $\left(E_{\mathrm{t}}\right)$ composed of the initiation energy $\left(E_{\mathrm{i}}\right)$ and propagation energy $\left(E_{\mathrm{p}}\right)$ is the area below the curve. Table VII shows the Charpy absorbed energy data $\left(E_{\mathrm{i}}, E_{\mathrm{p}}\right.$, and $\left.E_{\mathrm{t}}\right)$ measured at room temperature and $253 \mathrm{~K}\left(-20^{\circ} \mathrm{C}\right)$. The total absorbed energy of the M1-30 specimen is excellent $(238 \mathrm{~J})$ at room temperature but abruptly decreases down to $37 \mathrm{~J}$ at $253 \mathrm{~K}\left(-20^{\circ} \mathrm{C}\right)$. On the other hand, the total absorbed energies of the O4-30 and O4-50 specimens 
Table V. Volume Fractions of Bainitic Ferrite, Acicular Ferrite, Granular Bainite, Martensite-Austenite Constituent, and Prior Austenite Grain Size, and Effective Grain Size of the simulated Steel HAZ Specimens

\begin{tabular}{lcccccc}
\hline $\begin{array}{l}\text { Steel HAZ } \\
\text { Specimen }\end{array}$ & $\begin{array}{c}\text { Bainitic } \\
\text { Ferrite }(\mathrm{pct})\end{array}$ & $\begin{array}{c}\text { Acicular } \\
\text { Ferrite }(\mathrm{pct})\end{array}$ & $\begin{array}{c}\text { Granular } \\
\text { Bainite }(\mathrm{pct})\end{array}$ & $\begin{array}{c}\text { Martensite-Austenite } \\
\text { Constituent }(\mathrm{pct})\end{array}$ & $\begin{array}{c}\text { Prior Austenite } \\
\text { Grain Size }(\mu \mathrm{m})\end{array}$ & $\begin{array}{c}\text { Effective Grain } \\
\text { Size* }(\mu \mathrm{m})\end{array}$ \\
\hline M1-30 & $57 \pm 7.8$ & $30 \pm 4.1$ & $8 \pm 2.7$ & $5 \pm 1.4$ & $62.8 \pm 9.2$ & $32.4 \pm 3.4$ \\
M1-50 & $61 \pm 11.8$ & $26 \pm 7.4$ & $9 \pm 3.2$ & $4 \pm 1.7$ & $3 \pm 1.1$ & $78.5 \pm 14.8$ \\
M4-30 & $54 \pm 7.3$ & $38 \pm 4.8$ & $5 \pm 2.0$ & $2 \pm 0.7$ & $27.8 \pm 3.5$ \\
M4-50 & $58 \pm 10.8$ & $35 \pm 8.1$ & $5 \pm 2.2$ & $4 \pm 0.9$ & $80.8 \pm 11.0$ \\
O4-30 & $30 \pm 7.6$ & $63 \pm 5.6$ & $3 \pm 1.2$ & $3 \pm 1.3$ & $22.3 \pm 3.1$ \\
O4-50 & $44 \pm 9.7$ & $49 \pm 6.1$ & $4 \pm 1.9$ & $26.0 \pm 3.1$ \\
\hline
\end{tabular}

*Effective grain size measured from the EBSD analysis.

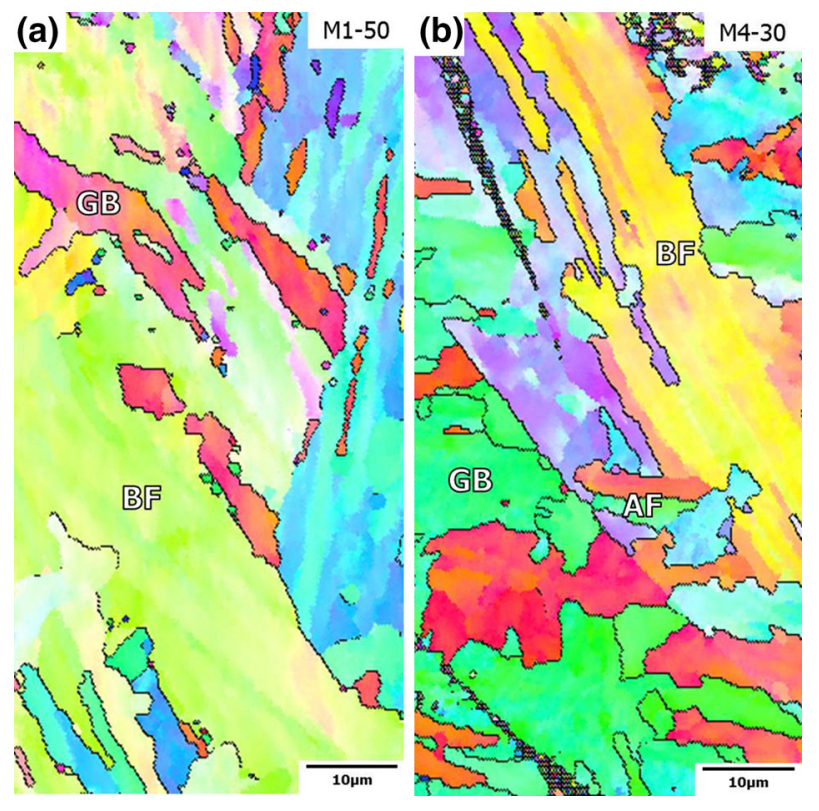

Fig. 5-Inverse pole figure (IPF) color maps of the (a) M1-50 and (b) M4-30 specimens after the HAZ simulation test.

Table VI. Room-Temperature Tensile Properties of the Simulated Steel HAZ Specimens

\begin{tabular}{lccc}
\hline $\begin{array}{l}\text { Steel } \\
\text { HAZ } \\
\text { Specimen }\end{array}$ & $\begin{array}{c}\text { Yield } \\
\text { Strength } \\
(\mathrm{MPa})\end{array}$ & $\begin{array}{c}\text { Ultimate } \\
\text { Tensile } \\
\text { Strength }(\mathrm{MPa})\end{array}$ & $\begin{array}{c}\text { Elongation } \\
\text { (pct) }\end{array}$ \\
\hline M1-30 & $579 \pm 6$ & $689 \pm 8$ & $23 \pm 1.8$ \\
M1-50 & $677 \pm 8$ & $744 \pm 9$ & $18 \pm 0.7$ \\
M4-30 & $615 \pm 6$ & $701 \pm 7$ & $22 \pm 1.9$ \\
M4-50 & $626 \pm 9$ & $678 \pm 8$ & $19 \pm 1.1$ \\
O4-30 & $586 \pm 7$ & $669 \pm 10$ & $24 \pm 2.6$ \\
O4-50 & $584 \pm 8$ & $659 \pm 9$ & $22 \pm 1.4$ \\
\hline
\end{tabular}

are good even at the test temperature of $253 \mathrm{~K}$ $\left(-20^{\circ} \mathrm{C}\right)$, although the energy decreases with decreasing test temperature. The total energy is similar at about 150 to $240 \mathrm{~J}$ at room temperature in all the specimens, whereas it tends to increase in the order of the M1, M4, and $\mathrm{O} 4$ steel specimens at $253 \mathrm{~K}\left(-20^{\circ} \mathrm{C}\right)$. The initiation energy of all the specimens is almost constant (about $75 \mathrm{~J}$ ) at room temperature.

SEM fractographs of the Charpy impact specimens fractured at $253 \mathrm{~K}\left(-20^{\circ} \mathrm{C}\right)$ of the HAZ specimens are shown in Figures 7(a) through (f). In the Charpy specimen, a shear zone is located in front of the notch tip as a slip line field is formed during the Charpy impact test ${ }^{[31,32]}$ and affects the fracture initiation. In Figures 7(a) through (f), the shear zone is visible in front of the machined notch tip as marked by yellow arrows, and its width is varied in each HAZ specimen. Since it is formed by a ductile dimpled mode, it is easily differentiated from the machined notch or the fracture propagation zone. The shear zone widths of the Charpy impact specimens fractured at room temperature and $253 \mathrm{~K}$ $\left(-20^{\circ} \mathrm{C}\right)$ were measured, and the results are shown in Table VIII. The shear zone widths in the case of room temperature are almost constant at about 210 to $220 \mu \mathrm{m}$, irrespective of HAZ specimen. On the other hand, the shear zone widths in the case of $253 \mathrm{~K}$ $\left(-20{ }^{\circ} \mathrm{C}\right)$ increase in the order of the M1, M4, and $\mathrm{O} 4$ steel HAZ specimens, and are larger in the 30-series specimens than in the 50 -series specimens.

\section{E. Fracture Toughness of Simulated HAZ of API X80 Linepipe Steels}

The plane strain fracture toughness test results measured at room temperature and $253 \mathrm{~K}\left(-20{ }^{\circ} \mathrm{C}\right)$ are listed in Table IX. The fracture toughness of the M1-30 specimen is excellent (131 MPa $\sqrt{\mathrm{m}})$ at room temperature but abruptly decreases down to 14.5 $\mathrm{MPa} \sqrt{\mathrm{m}}$ at $253 \mathrm{~K}\left(-20^{\circ} \mathrm{C}\right)$. The fracture toughness values of the O4-30 and O4-50 specimens are not much reduced with decreasing temperature. Thus, it increases in the order of the M1, M4, and O4 steel HAZ specimens at $253 \mathrm{~K}\left(-20^{\circ} \mathrm{C}\right)$.

SEM fractographs of the fracture toughness specimens fractured at $253 \mathrm{~K}\left(-20^{\circ} \mathrm{C}\right)$ of the HAZ specimen are shown in Figures 8(a) through (f). In the fracture toughness specimen, a stretch zone is located in front of the pre-fatigued crack tip, because the crack tip is blunted in the initial stage of fracture by the formation of a plastic zone, ${ }^{[33]}$ as marked by double-headed arrows. The stretch zone is formed shallow by a ductile dimpled mode and is differentiated from the prefatigued crack tip or the fracture propagation zone. The fracture propagation zone is composed of ductile dimples in the O4-30 specimen, whereas the cleavage mode is predominant in other specimens. The measured stretch zone widths are shown in Table VIII. They are much smaller than the shear zone widths of the Charpy 


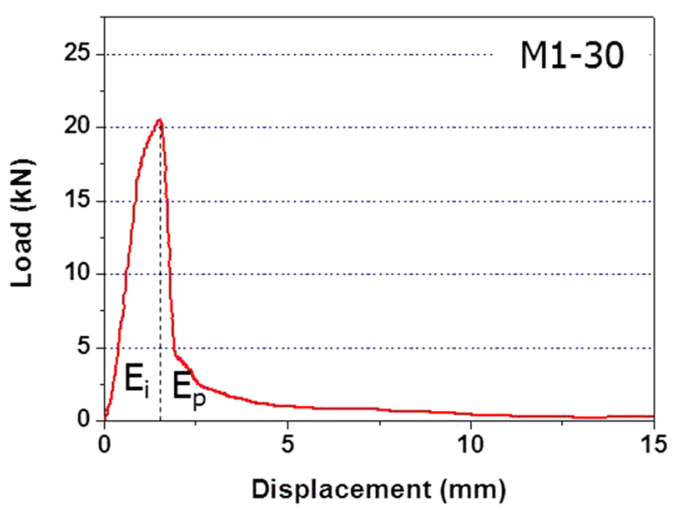

(a)

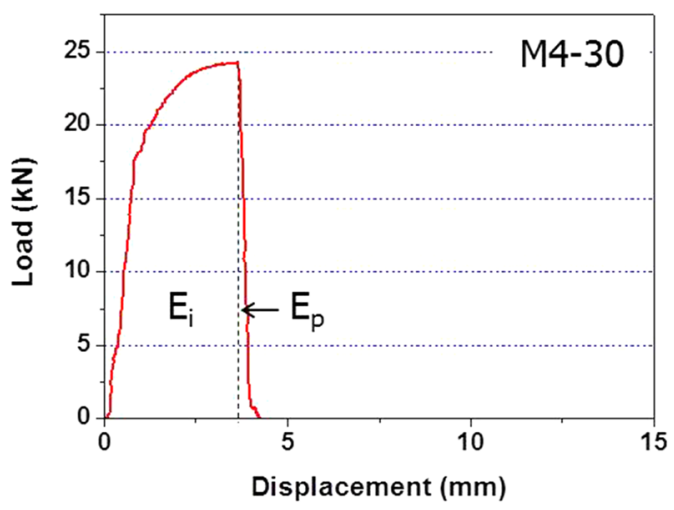

(c)

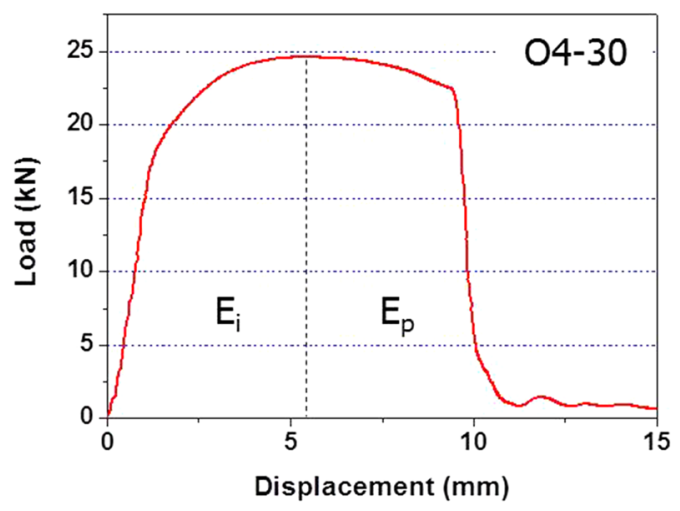

(e)



(b)

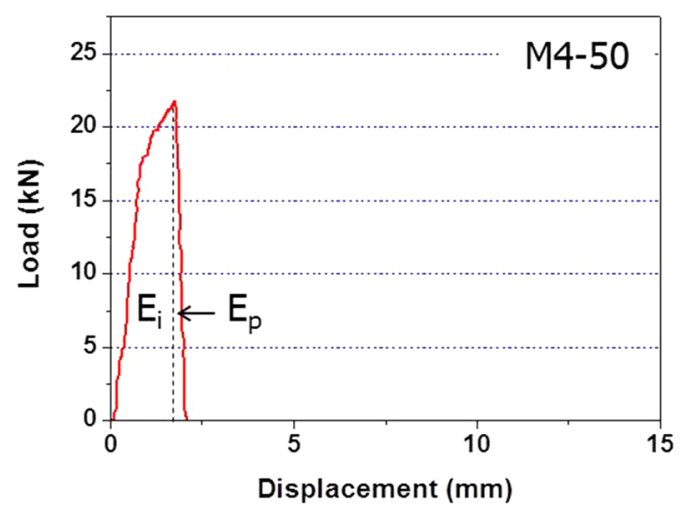

(d)

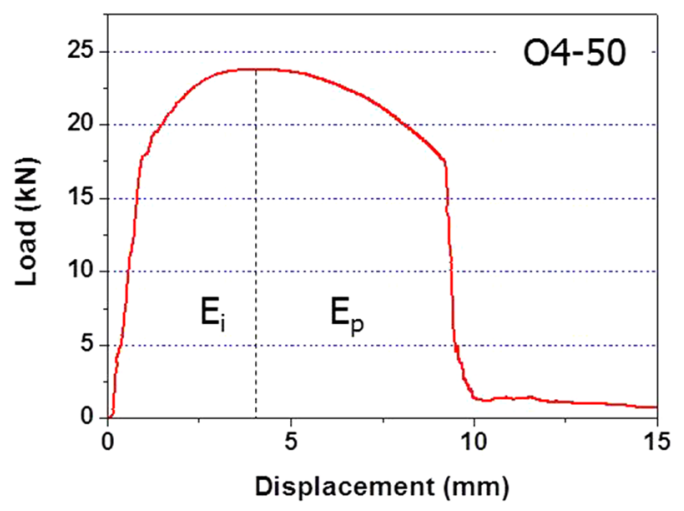

(f)

Fig. 6-Load-displacement curves obtained from the instrumented Charpy system at $253 \mathrm{~K}\left(-20{ }^{\circ} \mathrm{C}\right)$ of the (a) M1-30, (b) M1-50, (c) M4-30, (d) M4-50, (e) O4-30, and (f) O4-50 specimens.

Table VII. Charpy Impact Properties Tested at Room Temperature and $253 \mathrm{~K}\left(-20{ }^{\circ} \mathrm{C}\right)$ of the Simulated Steel HAZ Specimens

\begin{tabular}{|c|c|c|c|c|c|c|}
\hline \multirow[b]{2}{*}{ Steel HAZ Specimen } & \multicolumn{3}{|c|}{ Room Temperature } & \multicolumn{3}{|c|}{$253 \mathrm{~K}\left(-20^{\circ} \mathrm{C}\right)$} \\
\hline & $E_{\mathrm{i}}^{*}(\mathrm{~J})$ & $E_{\mathrm{p}}^{*}(\mathrm{~J})$ & $E_{\mathrm{t}}^{*}(\mathrm{~J})$ & $E_{\mathrm{i}}^{*}(\mathrm{~J})$ & $E_{\mathrm{p}}^{*}(\mathrm{~J})$ & $E_{\mathrm{t}}^{*}(\mathrm{~J})$ \\
\hline M1-30 & $80.0 \pm 7.2$ & $158.1 \pm 23.3$ & $238.0 \pm 30.5$ & $15.6 \pm 3.1$ & $21.4 \pm 1.2$ & $37.0 \pm 4.2$ \\
\hline M1-50 & $73.5 \pm 3.3$ & $79.7 \pm 3.7$ & $153.2 \pm 7.0$ & $4.3 \pm 1.2$ & $15.3 \pm 1.7$ & $19.6 \pm 0.5$ \\
\hline M4-30 & $72.8 \pm 0.2$ & $165.8 \pm 32.6$ & $238.6 \pm 32.4$ & $52.3 \pm 13.9$ & $6.9 \pm 0.9$ & $59.2 \pm 13.0$ \\
\hline M4-50 & $77.5 \pm 0.7$ & $162.8 \pm 11.3$ & $240.3 \pm 12.1$ & $35.8 \pm 13.1$ & $6.3 \pm 0.7$ & $42.1 \pm 12.4$ \\
\hline $\mathrm{O} 4-30$ & $73.3 \pm 0.2$ & $134.6 \pm 10.6$ & $207.9 \pm 10.4$ & $77.1 \pm 0.2$ & $61.2 \pm 22.0$ & $138.3 \pm 22.3$ \\
\hline O4-50 & $79.3 \pm 5.8$ & $137.9 \pm 20.5$ & $217.2 \pm 26.3$ & $45.2 \pm 31.6$ & $68.8 \pm 57.0$ & $114.0 \pm 88.6$ \\
\hline
\end{tabular}

$* E_{\mathrm{i}}$ (fracture initiation energy) $+E_{\mathrm{p}}$ (fracture propagation energy) $=E_{\mathrm{t}}$ (total energy). 

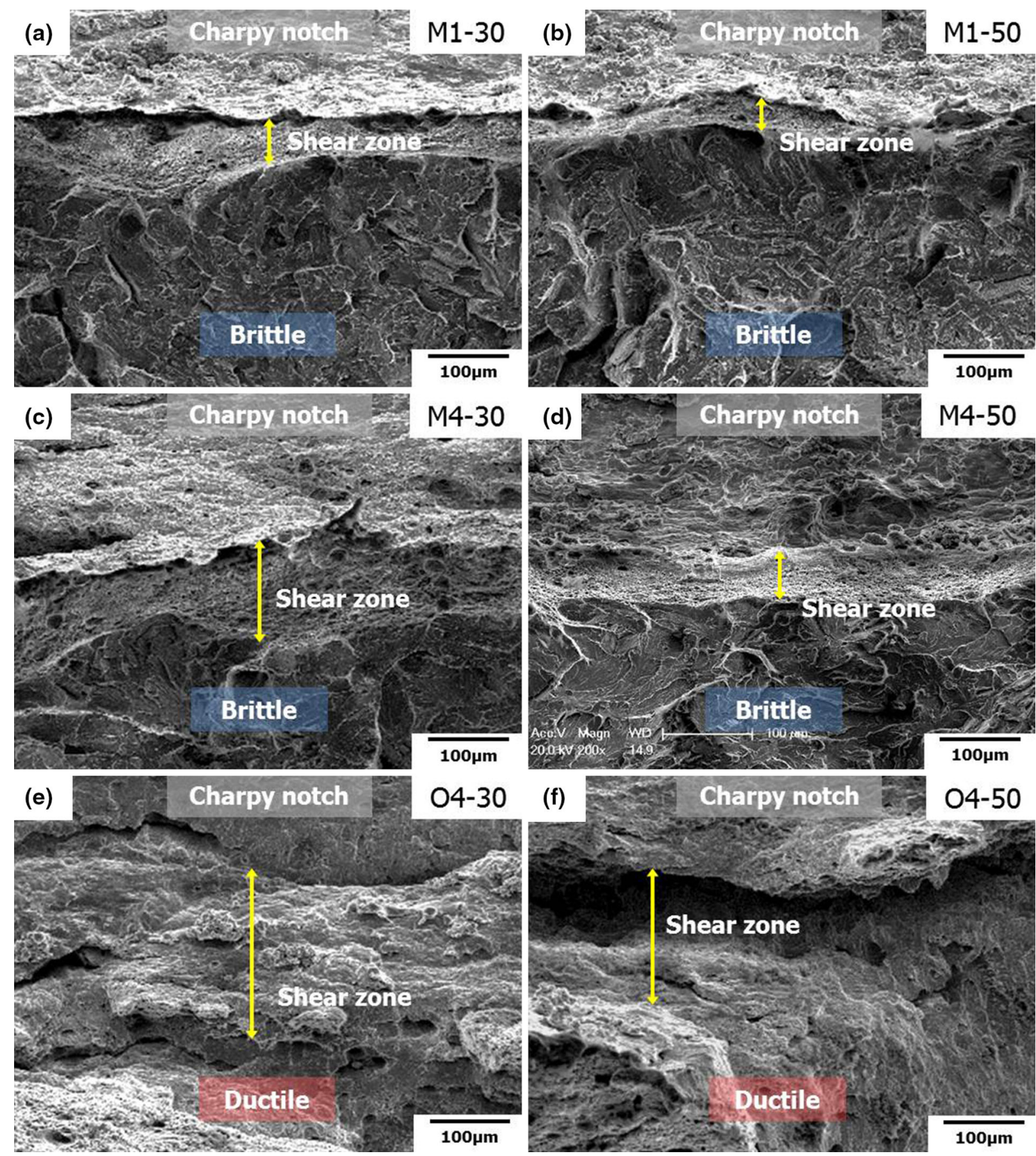

Fig. 7- SEM fractographs of the Charpy impact specimen fractured at $253 \mathrm{~K}\left(-20{ }^{\circ} \mathrm{C}\right)$ of the simulated HAZ specimen: $(a)$ M1-30, $(b)$ M1-50, (c) M4-30, (d) M4-50, (e) O4-30, and ( $f$ ) O4-50 specimens. The shear zone is located in front of the machined notch tip as marked by yellow arrows.

impact specimen and increase in the order of the M1, M4, and O4 steel specimens. Their trend is roughly matched with that of the fracture toughness (Table IX).

\section{DISCUSSION}

The simulated HAZ microstructures of API X80 linepipe steels mainly consist of $\mathrm{BF}, \mathrm{AF}, \mathrm{GB}$, and $\mathrm{MA}$ constituent, as mentioned in the Section III-C. The M1-30 and M1-50 specimens are mainly composed of BF, with minor presence of $\mathrm{AF}$, while $\mathrm{AF}$ is mainly formed besides $\mathrm{BF}$ in the O4-30 and O4-50 specimens (Table V). When the heat input increases, the volume fraction of $\mathrm{AF}$ is reduced by the slower cooling rate. These variations in the HAZ microstructure are attributed to the presence of complex oxides working as nucleation sites for AF inside the HAZ. ${ }^{[34]}$ Since oxides inside 
Table VIII. Shear Zone Width of the Charpy Impact Specimen and Stretch Zone Width of the Fracture Toughness Specimen Tested of the Simulated Steel HAZ Specimens

\begin{tabular}{llcc}
\hline & \multicolumn{2}{c}{ Shear Zone Width $(\mu \mathrm{m})$} & $\begin{array}{c}\text { Stretch Zone } \\
\text { Width }(\mu \mathrm{m})\end{array}$ \\
\cline { 2 - 3 } $\begin{array}{l}\text { Steel HAZ } \\
\text { Specimen }\end{array}$ & $\begin{array}{c}\text { Room } \\
\text { Temperature }\end{array}$ & $253 \mathrm{~K}\left(-20^{\circ} \mathrm{C}\right)$ & $253 \mathrm{~K}\left(-20^{\circ} \mathrm{C}\right)$ \\
\hline M1-30 & $213.9 \pm 10.4$ & $56.3 \pm 4.8$ & $3.1 \pm 0.7$ \\
M1-50 & $225.5 \pm 7.3$ & $42.3 \pm 4.1$ & $6.3 \pm 1.1$ \\
M4-30 & $214.3 \pm 16.7$ & $126.8 \pm 10.1$ & $10.2 \pm 1.7$ \\
M4-50 & $220.8 \pm 13.8$ & $80.4 \pm 5.9$ & $14.0 \pm 2.6$ \\
O4-30 & $207.9 \pm 15.9$ & $211.3 \pm 16.1$ & $51.2 \pm 6.6$ \\
O4-50 & $212.4 \pm 12.3$ & $156.9 \pm 13.0$ & $29.4 \pm 5.7$ \\
\hline
\end{tabular}

Table IX. Fracture Toughness Tested at Room Temperature and $253 \mathrm{~K}\left(-20^{\circ} \mathrm{C}\right)$ of the Simulated Steel HAZ Specimens

\begin{tabular}{|c|c|c|}
\hline $\begin{array}{l}\text { Steel } \\
\text { HAZ } \\
\text { Specimen }\end{array}$ & $\begin{array}{c}\text { Fracture } \\
\text { Toughness at } \\
\text { Room Temperature } \\
(\mathrm{MPa} \sqrt{\mathrm{m}})\end{array}$ & $\begin{array}{c}\text { Fracture } \\
\text { Toughness at } \\
253 \mathrm{~K}\left(-20{ }^{\circ} \mathrm{C}\right) \\
(\mathrm{MPa} \sqrt{\mathrm{m}})\end{array}$ \\
\hline M1-30 & $131 \pm 15.2$ & $14.5 \pm 1.7$ \\
\hline M1-50 & $105 \pm 12.1$ & $26.0 \pm 3.3$ \\
\hline M4-30 & $124 \pm 14.4$ & $28.7 \pm 2.9$ \\
\hline M4-50 & $85 \pm 9.0$ & $50.7 \pm 5.6$ \\
\hline $\mathrm{O} 4-30$ & $110 \pm 11.2$ & $93.4 \pm 12.1$ \\
\hline O4-50 & $123 \pm 16.3$ & $55.6 \pm 6.9$ \\
\hline
\end{tabular}

austenite grains in the HAZ provide nucleation sites, AFs are formed around oxides, whereas other regions are mostly composed of $\mathrm{BF}$ or $\mathrm{GB} \cdot{ }^{[7,8]}$ In spite of the presence of a considerable amount of oxides in the M1 steel, the volume fraction of AF is twice lower than that of the $\mathrm{O} 4$ steel. In order to explain this, effects of the size and no. of oxides on nucleation of AF need to be examined.

According to Barbaro et al.,${ }^{[13]}$ AFs are well nucleated when non-metallic oxides are larger than $0.5 \mu \mathrm{m}$. In the present steels, most of oxides larger than $0.5 \mu \mathrm{m}$ can work as nucleation sites for AF. The no. of oxides in the $\mathrm{O} 4$ steel is about the double of the M1 steel. This larger no. beneficially affects the formation of AF in the HAZ, like in the $\mathrm{O} 4$ steel HAZ specimens. ${ }^{[35]}$ To interpret the large increase in volume fraction of AF in the $\mathrm{O} 4$ steel HAZ specimens, additional microstructural factor of austenite grain size (AGS) should be taken into consideration. During the austenite-ferrite transformation, the AGS affects the formation of AF in the HAZ, because both austenite grain boundaries and oxides can work as ferrite nucleation sites. Bhadeshia ${ }^{[14]}$ reported that AF is well formed when the AGS exceeds a certain size level. Since austenite grain boundaries require the lower activation energy for the transformation than oxides, they provide nucleation sites at a low degree of supercooling, thereby leading to the ready formation of bainite. On the other hand, oxides require relatively higher activation energy, and thus, AF is readily nucleated at a higher degree of supercooling. When the AGS is large enough to provide a sufficient space, ferrites are nucleated at oxides, in spite of the fast transformation at austenite grain boundaries. When the AGS is too small, oxides cannot work effectively as ferrite nucleation sites, because microstructures such as bainite transformed from austenite grain boundaries occupy the interior space of austenite grains. In the present study, the AGS of the O4 steel $81 \mu \mathrm{m}$, which is larger than that of the M1 steel $(63 \mu \mathrm{m})$, and this larger AGS readily provides the ample formation of AF in the HAZ.

The Charpy impact energy of the HAZ is greatly influenced by the HAZ microstructure and improves with increasing volume fraction of AF. Microstructural factors beneficially affecting the AF formation in the HAZ are the no. of oxides and AGS, as aforementioned above. Effects of volume fraction of AF on Charpy impact energy at room temperature and $253 \mathrm{~K}\left(-20{ }^{\circ} \mathrm{C}\right)$ are illustrated in Figures 9(a) and (b), respectively. Here, the total Charpy absorbed energy is divided into the fracture initiation and propagation energies, and the fracture mode is displayed by dark gray and light gray colors, depending on ductile dimpled and brittle cleavage modes, respectively. At room temperature, the ductile dimpled fracture is predominated (Figure 9(a)). The fracture initiation energy is maintained constant at about $75 \mathrm{~J}$, irrespective of volume fraction of AF. This can be confirmed by the measurement data of shear zone width which is remained constant at 210 to $220 \mu \mathrm{m}$ (Table VIII). The fracture propagation energy rapidly increases from 75 to $150 \mathrm{~J}$ and saturates when the volume fraction of AF exceeds $30 \mathrm{vol}$ pct. Thus, the total Charpy absorbed energy is almost constant at about $250 \mathrm{~J}$ or slightly decreases when the volume fraction of AF becomes higher than 30 pct, although it is expected that it increases almost linearly with increasing volume fraction of AF. This implies that about 30 vol pct of AF at least is needed for improving the Charpy impact energy in the case of ductile dimpled fracture at room temperature. In addition, in order to improve the Charpy impact energy, the fracture propagation energy should be raised more by forming AF, because the volume fraction of AF does not affect the fracture initiation energy much.

At $253 \mathrm{~K}\left(-20^{\circ} \mathrm{C}\right)$, the total absorbed energy increases linearly with increasing volume fraction of $\mathrm{AF}$, as the both fracture initiation and propagation energies tend to increase (Figure 9(b)). The brittle cleavage fracture is predominated at the volume fraction of AF of 45 pct or lower and is changed to the ductile dimpled fracture when the volume fraction of $\mathrm{AF}$ exceeds 45 pct. This result indicates that the Charpy impact energy is greatly affected by the volume fraction of AF, unlike in the case of room temperature at which the Charpy energy is hardly influenced by the volume fraction of AF. The reason for the proportional increase in Charpy impact energy due to the increased volume fraction of AF is associated with characteristics of tough and fine AF. As the volume fraction of AF increases, the total absorbed energy consisted of fracture initiation and propagation energies increases. This can be confirmed from the fractographic results of Figures 7(a) through (f). The shear zone width is plotted as a function of Charpy initiation energy and volume fraction of AF, 

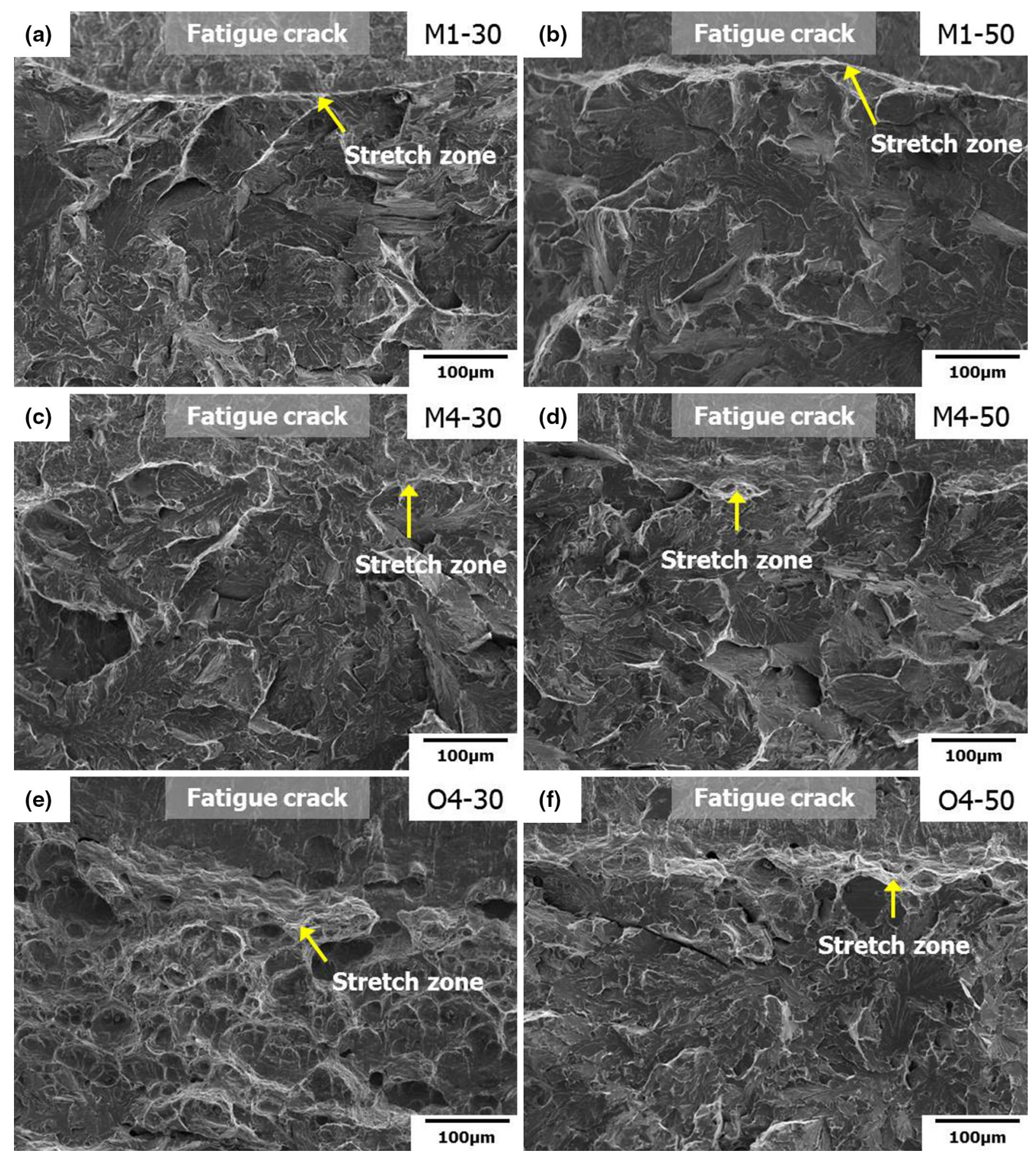

Fig. 8- SEM fractographs of the fracture toughness fractured at $253 \mathrm{~K}\left(-20^{\circ} \mathrm{C}\right)$ of the simulated HAZ specimen: $(a)$ M1-30, (b) M1-50, $(c)$ M4-30, (d) M4-50, (e) O4-30, and (f) O4-50 specimens. The stretch zone is located in front of the machined notch tip as marked by yellow arrows.

as shown in Figures 10(a) and (b), respectively. The width of shear zone developed in front of the notch tip increases linearly with increasing Charpy initiation energy (Figure 10(a)), because the shear zone is formed in a form of slip line field during the initial stage of Charpy impact test. ${ }^{[31,32]}$ Thus, it shows the same trend with the volume fraction of AF (Figure 10(b)). In addition, the fracture propagation energy increases with increasing volume fraction of $\mathrm{AF}$, as the brittle cleavage fracture mode is changed to the ductile dimpled fracture mode. This fracture mode transition is associated with the toughness of microstructures of $\mathrm{AF}$ and $\mathrm{BF}$. Particularly in the O4-30 and O4-50 specimens containing many AFs, the ductile dimpled fracture mode is observed on the fracture propagation region even at $253 \mathrm{~K}\left(-20^{\circ} \mathrm{C}\right)$ (Figures $7(\mathrm{e})$ and (f)). Thus, about $45 \mathrm{vol}$ pct of AF at least is needed for improving the Charpy impact energy at $253 \mathrm{~K}\left(-20^{\circ} \mathrm{C}\right)$, which can be 


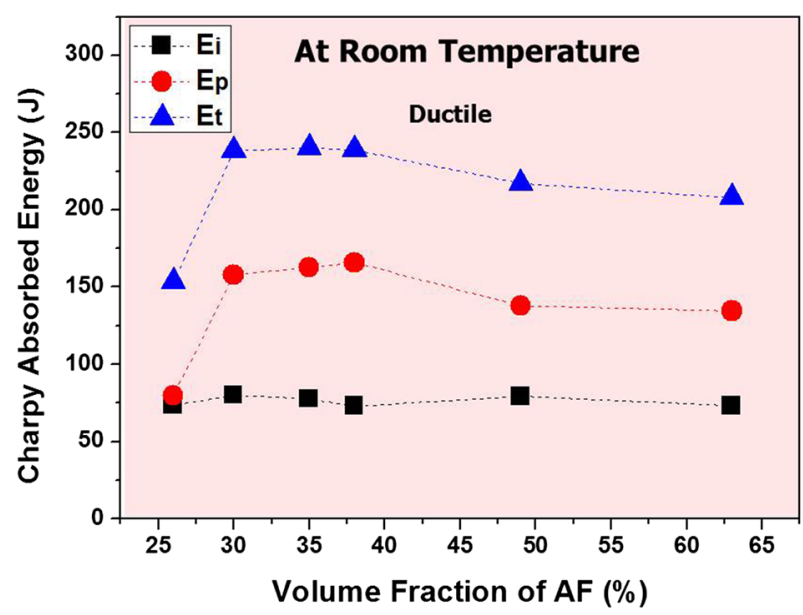

(a)

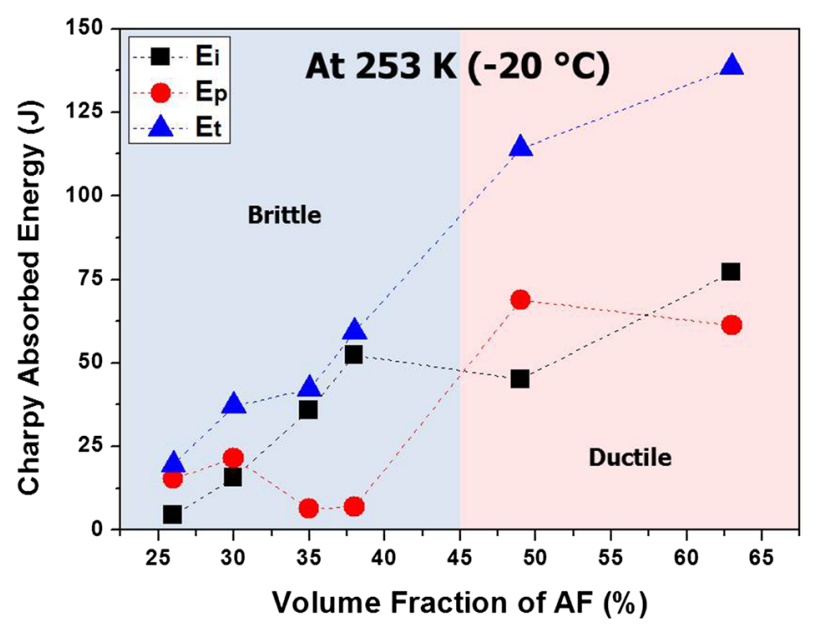

(b)

Fig. 9- Charpy absorbed energy as a function of volume fraction of acicular ferrite at $(a)$ room temperature and $(b) 253 \mathrm{~K}\left(-20^{\circ} \mathrm{C}\right)$. The total Charpy absorbed energy $\left(E_{\mathrm{t}}\right)$ is divided into the fracture initiation energy $\left(E_{\mathrm{i}}\right)$ and propagation energy $\left(E_{\mathrm{p}}\right)$, and the fracture mode is displayed by light red and blue colors, depending on ductile dimpled and brittle cleavage modes, respectively.

achieved by forming a no. of oxides, as in the $\mathrm{O} 4$ steel specimens.

Effects of volume fraction of $\mathrm{AF}$ on fracture toughness and stretch zone width at $253 \mathrm{~K}\left(-20^{\circ} \mathrm{C}\right)$ are shown in Figures 11(a) and (b). The fracture toughness increases linearly with the volume fraction of AF (Figure 11(a)). This is because AF is a fine and tough microstructure mainly formed around oxides and beneficially influences to fracture toughness. The stretch zone width also increases with increasing volume fraction of AF (Figure 11(b)), as it has a close relation with the fracture toughness. Since the stretch zone is a blunted crack tip area formed in the initial stage of fracture, the fracture toughness increases, as the stretch zone is widened. ${ }^{[33]}$

Since oxides can work as crack or void initiation sites for the fracture initiation, it is readily expected that the fracture toughness decreases with increasing no. of oxides. ${ }^{[36]}$ Lee et $a l .{ }^{[37]}$ proposed a ductile fracture

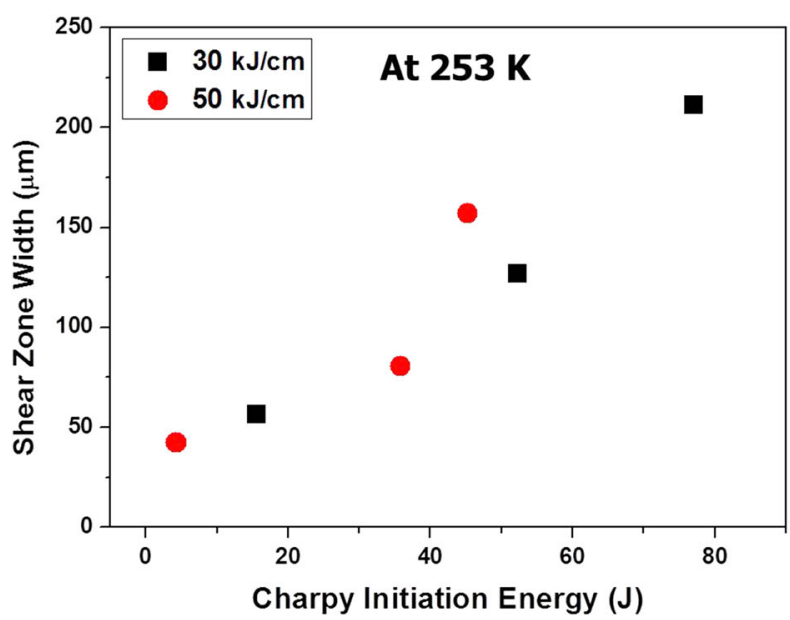

(a)

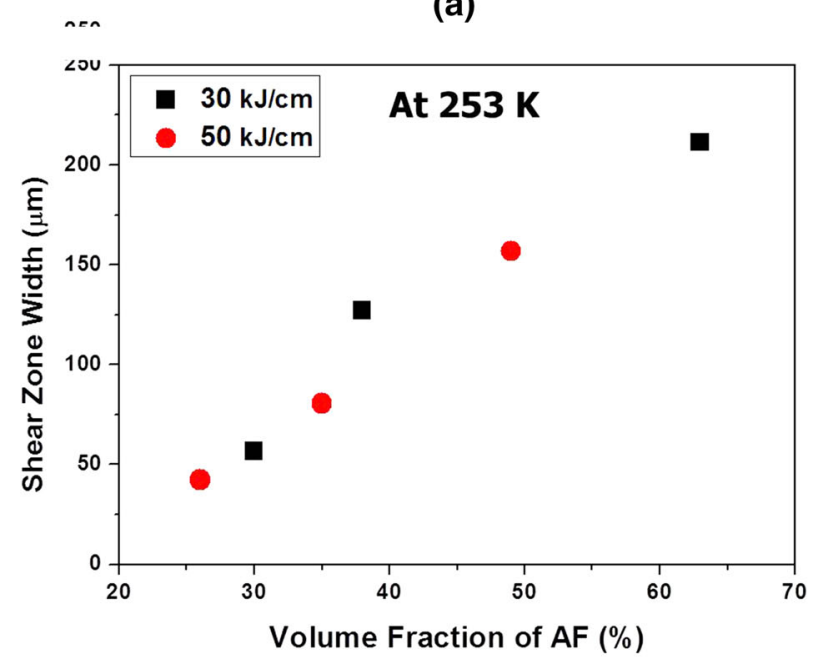

(b)

Fig. 10 - Shear zone width as a function of (a) Charpy initiation energy and $(b)$ volume fraction of acicular ferrite at $253 \mathrm{~K}\left(-20^{\circ} \mathrm{C}\right)$.

initiation model for analyzing the fracture toughness in high-strength steels and found that the spacing between crack and void initiation sites negatively worked for the fracture toughness, because cracks and voids were readily coalesced to form a long crack. The fracture toughness is critically influenced by volume fractions and distributions of voids or particles which affect the fracture initiation inside the material. ${ }^{[38]}$ Thus, the reduced spacing of crack or void initiation sites due to the reduced spacing between oxides can cause the reduction in fracture toughness. However, this explanation cannot be applied to the present case of the steel HAZ. Most of AFs are easily formed around oxides, as oxides provide nucleation sites for $\mathrm{AF}^{\left[{ }^{[-11]}\right.}$ Oxides cannot play a role sufficiently as crack or void initiation sites, because they are surrounded by tough $\mathrm{AFs}^{[16]}$ Thus, the reason why the fracture toughness increases with increasing no. of oxides is associated with the volume fraction of $\mathrm{AF}$ formed around oxides.

The relation of Charpy impact energy (total, initiation, and propagation energies) and fracture toughness measured at room temperature and $253 \mathrm{~K}\left(-20^{\circ} \mathrm{C}\right)$ are 


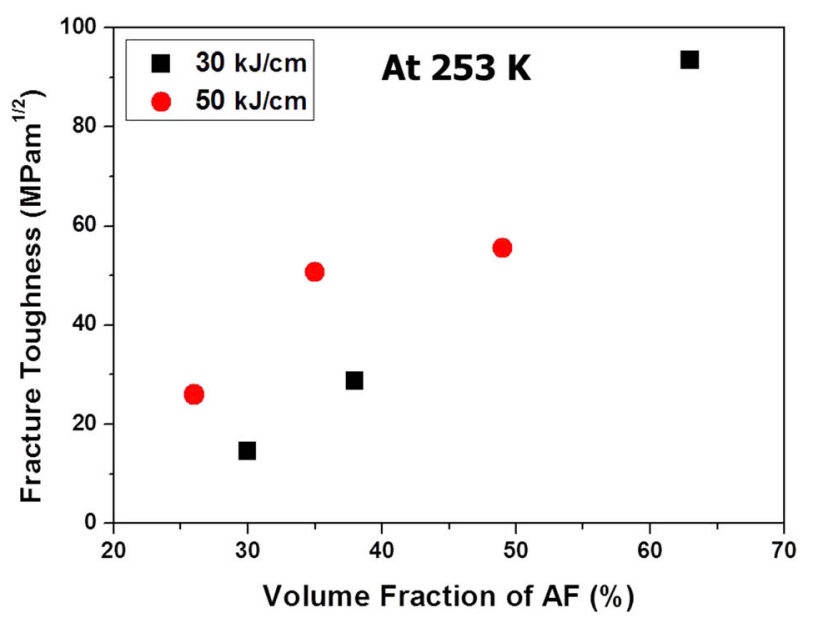

(a)

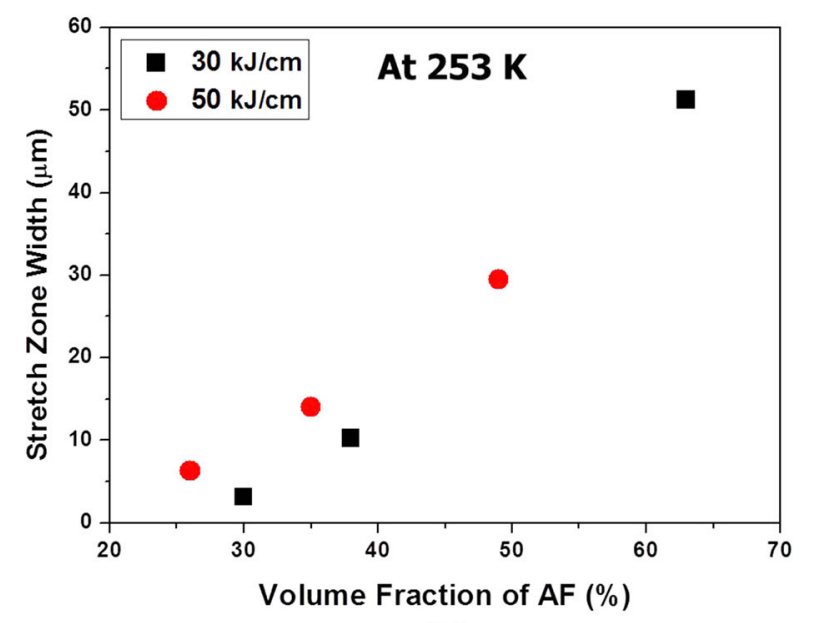

(b)

Fig. 11-(a) Fracture toughness and (b) stretch zone width measured at $253 \mathrm{~K}\left(-20^{\circ} \mathrm{C}\right)$ as a function of volume fraction of acicular ferrite.

shown in Figures 12(a) and (b). At room temperature, the fracture occurs in a ductile dimpled mode in the both Charpy impact and fracture toughness tests (Figure 12(a)). The total, initiation, propagation energies do not show a visible correlation with the fracture toughness, because the fracture initiation energy remains constant with increasing fracture toughness. The reason for this irrelevance is basically associated with the difference in testing methods. ${ }^{[39]}$ In the Charpy impact test method, the specimen is momentarily subjected to very high energy by the impact of a heavy hammer under a dynamic loading condition, and the energy absorbed in the specimen contains both initiation and propagation energies of a crack initiated from a V-shaped notch. On the other hand, the fracture toughness test method is quasi-statically performed and shows the stress intensity at the time of initiation of crack growth at a sharp pre-fatigue-crack tip region. ${ }^{[36]}$ Toughness properties obtained from these two toughness testing methods have different significations in view of fracture mechanics.

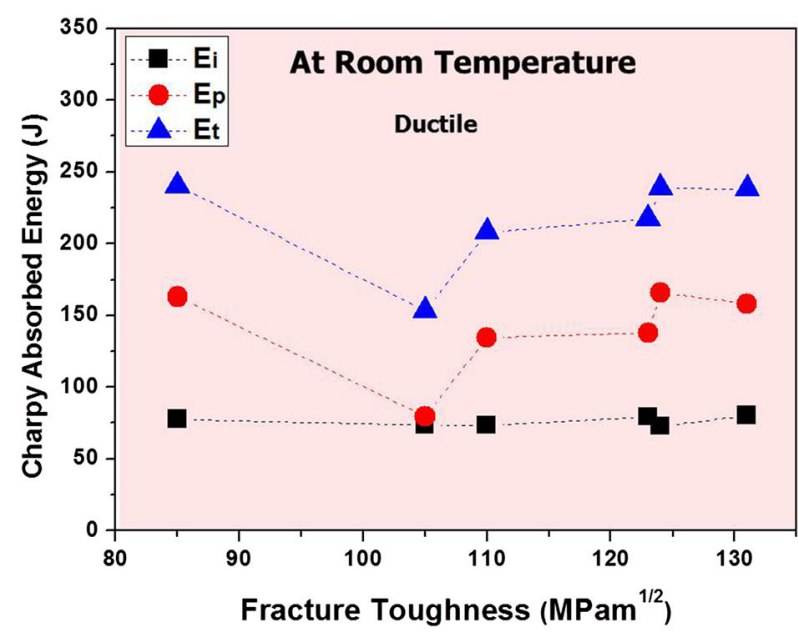

(a)

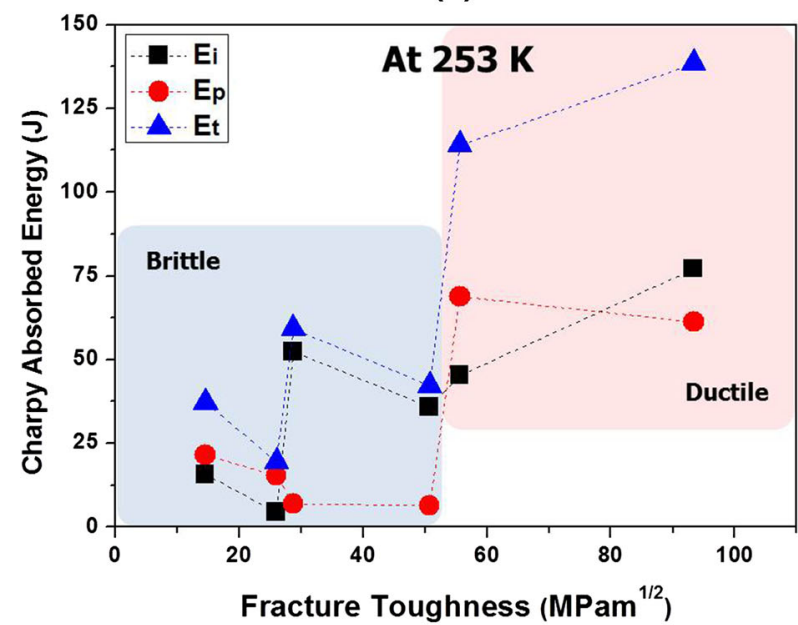

(b)

Fig. 12 - Charpy absorbed energy as a function of volume fraction of acicular ferrite at $(a)$ room temperature and $(b) 253 \mathrm{~K}\left(-20{ }^{\circ} \mathrm{C}\right)$. The total Charpy absorbed energy $\left(E_{\mathrm{t}}\right)$ is divided into the fracture initiation energy $\left(E_{\mathrm{j}}\right)$ and propagation energy $\left(E_{\mathrm{p}}\right)$, and the fracture mode is displayed by light red and blue colors, depending on ductile dimpled and brittle cleavage modes, respectively.

At $253 \mathrm{~K}\left(-20^{\circ} \mathrm{C}\right)$, the total absorbed energy increases proportionally with fracture toughness (Figure 12(b)), although the initiation and propagation energies are somewhat varied with fracture toughness. The brittle cleavage fracture is changed to the ductile dimpled fracture when the total absorbed energy and fracture toughness exceed $90 \mathrm{~J}$ and $53 \mathrm{MPa} \sqrt{\mathrm{m}}$, respectively. This indicates that the Charpy impact energy and fracture toughness follow the general toughness trend, unlike in the case of room temperature. The reason for the correlation of Charpy impact energy and fracture toughness is associated with volume fraction of $\mathrm{AF}$, because both the Charpy impact energy and fracture toughness increase with increasing volume fraction of AF as shown in Figures 9(b) and 11(a). This can also be confirmed from the fractographic results of Figures 8(a) through (f) and relations among fracture toughness, stretch zone width, and volume fraction of AF of Figures 11(a) and (b). 
Based on the above results, toughness properties of the API X80 linepipe steel HAZ can be improved using the oxide metallurgy technology. They can also be correlated with the volume fraction of AF formed in the HAZ and the no. of oxides under different heat input conditions in order to determine the optimized no. of oxides and welding conditions in advance. In view of microstructural aspects, AF nucleated from oxides inside austenite grains is desirable for improving toughness properties, which can be reasonably explained by the volume fraction of AF. In view of mechanical aspects, the Charpy toughness shows the somewhat different behaviors from the fracture toughness, because the Charpy impact energy is composed of fracture initiation and propagation energies in a notched body, whereas the fracture initiation at the sharp crack tip is significantly considered in the fracture toughness. This oxide metallurgy technology can be applied to grain refinement by inhomogeneous nucleation when the large-scale welding or large deformation is needed, like in the cases of steel plates requiring higher heat inputs during welding.

\section{CONCLUSIONS}

In the present study, complex oxides were formed by adding $\mathrm{Mg}$ and $\mathrm{O}_{2}$ to the API X80 linepipe steels, and effects of these oxides on HAZ microstructures, Charpy impact properties, and fracture toughness were investigated.

1. Oxides present in the API X80 linepipe steels were complex oxides sized by 0.9 to $1.4 \mu \mathrm{m}$, and the total no. of oxides increased in the order of the M1, M4, and $\mathrm{O} 4$ steels (in the order of total amount of $\mathrm{O}_{2}$ or $\mathrm{Mg}$ ). When the total Charpy absorbed energy was divided into the fracture initiation and propagation energies, the fracture initiation energy was maintained constant at about $75 \mathrm{~J}$ at room temperature, irrespective of volume fraction of AF. The fracture propagation energy rapidly increased from 75 to $150 \mathrm{~J}$ and saturated when the volume fraction of AF exceeded 30 pct. To improve the Charpy impact energy at room temperature, thus, the fracture propagation energy should be raised more, and about 30 vol pct of $\mathrm{AF}$ at least was needed.

2. At $253 \mathrm{~K}\left(-20{ }^{\circ} \mathrm{C}\right)$, the total absorbed energy increased linearly with increasing volume fraction of $\mathrm{AF}$, as the both fracture initiation and propagation energies tended to increase. The brittle cleavage fracture was predominated at the volume fraction of AF of 45 pct or lower, and was changed to the ductile dimpled fracture when the volume fraction of AF exceeded 45 pct. Thus, $45 \mathrm{vol}$ pct of AF at least was needed to improve the Charpy impact energy at $253 \mathrm{~K}\left(-20^{\circ} \mathrm{C}\right)$, which could be achieved by forming a no. of oxides, as in the $\mathrm{O} 4$ steel HAZ specimens.

3. Since oxides could work as crack or void initiation sites for the fracture initiation, it was expected that the fracture toughness decreased with increasing no. of oxides. However, this expectation was not applied to the present steel HAZs. Oxides did not play a role sufficiently as crack or void initiation sites, because they were surrounded by tough AF. Thus, the fracture toughness increased with increasing the no. of oxides because of the increased volume fraction of AF formed around oxides.

4. The Charpy absorbed energy (total, initiation, and propagation energies) did not show a visible correlation with the fracture toughness at room temperature, because toughness properties obtained from these two toughness testing methods had different significations in view of fracture mechanics. At $253 \mathrm{~K}\left(-20^{\circ} \mathrm{C}\right)$, however, the Charpy absorbed energy was proportionally correlated with the fracture toughness, because both the Charpy impact energy and fracture toughness increased with increasing volume fraction of AF.

\section{ACKNOWLEDGMENTS}

This work was supported by the Ministry of Knowledge Economy under a Grant No. 100400-25. The authors would like to thank Dr. Woo-Yeol Cha of POSCO for his help of the processing of the linepipe steels.

\section{REFERENCES}

1. K.T. Corbett, R.R. Bowen, and C.W. Petersen: Int. J. Offshore Polar Eng., 2004, vol. 14, pp. 75-80.

2. R. Denys: Pipeline Technology, Elsevier, Amsterdam, 2000, vol. I \& II.

3. Y.T. Shin and H.W. Lee: Met. Mater. Int., 2012, vol. 18, pp. 86367.

4. D.P. Fairchild, M.L. Macia, S.D. Papka, C.W. Petersen, J.H. Stevens, S.T. Barbas, N.V. Bangaru, J.Y. Koo, and M.J. Luton: Proceedings of the International Pipe Dreamer's Conference, Yokohama, 2002, pp. 307-21.

5. T. Koseki, H. Kato, M. Tsutsumi, K. Kasai, and J. Inoue: Int. J. Mater. Res., 2008, vol. 99, pp. 347-51.

6. J.-S. Byun, J.-H. Shim, Y.W. Cho, and D.N. Lee: Acta Mater., 2003, vol. 51, pp. 1593-1606.

7. S.S. Babu: Curr. Opin. Solid State Mater., 2004, vol. 8, pp. 267-78.

8. J.-H. Shim, Y.J. Oh, J.Y. Suh, Y.W. Cho, J.-D. Shim, J.S. Byun, and D.N. Lee: Acta Mater., 2001, vol. 49, pp. 2115-22.

9. S.Y. Shin, K. Oh, K.B. Kang, and S. Lee: Mater. Sci. Technol., 2010 , vol. 26 , pp. $1049-58$.

10. T. Maki: Mater. Jpn., 1997, vol. 36, pp. 937-40.

11. J.M. Gregg and H.K.D.K. Bhadeshia: Acta Mater., 1997, vol. 45, pp. 739-48.

12. M. Enomoto: Met. Mater., 1998, vol. 4, pp. 115-23.

13. F.J. Barbaro, P. Krauklis, and K.E. Easterling: Mater. Sci. Technol., 1989, vol. 5, pp. 1057-68.

14. H.K.D.H. Bhadeshia: Bainite in Steels, 2nd ed., IOM Communications Ltd., London, 2001.

15. Y.T. Shin, H.S. Shin, and H.W. Lee: Met. Mater. Int., 2012, vol. 18 , pp. 1037-40.

16. S.Y. Shin, K. Oh, K.B. Kang, and S. Lee: ISIJ Int., 2009, vol. 49 (8), pp. 1191-99.

17. W. Cha, K. Oh, and J.Y. Cho: Kor. Patent No. 10-2010-0102442, 2010.

18. I. Tamura, H. Sekine, T. Tanaka, and C. Ouchi: Thermomechanical Processing of High-Strength Low-Alloy Steels, Butterworth \& Co., Ltd., London, 1988, pp. 80-100.

19. S. Vervynckt, P. Thibaux, and K. Verbeken: Mater. Int., 2012, vol. 18 , pp. $37-46$. 
20. S. Kim and C. Lee: Met. Mater. Int., 2012, vol. 18, pp. 857-62.

21. M. Diaz-Fuentes, A. Iza-Mendia, and I. Gutierrez: Metall. Mater. Trans. A, 2003, vol. 34A, pp. 2505-16.

22. ASTM Standard E8/E8M-11: Standard Test Methods for Tension Testing of Metallic Materials, Annual Book of ASTM Standards, ASTM, West Conshohocken, PA, 2011.

23. ASTM Standard E23-12c: Standard Test Method for Notched Bar Impact Testing of Metallic Materials, Annual Book of ASTM Standards, ASTM, West Conshohocken, PA, 2012.

24. ASTM Standard E2298-09: Standard Test Method for Instrumented Impact Testing of Metallic Materials, Annual Book of ASTM Standards, ASTM, West Conshohocken, PA, 2009.

25. ASTM Standard E1921-12: Standard Test Method for Determination of Reference Temperature, $T_{o}$, for Ferritic Steels in the Transition Range, Annual Book of ASTM Standards, ASTM, West Conshohocken, PA, 2012.

26. C.H. Lee, H.K.D.H. Bhadeshia, and H.-C. Lee: Mater. Sci. Eng., 2003, vol. A360, pp. 249-57.

27. G. Krauss and S.W. Thompson: ISIJ Int., 1995, vol. 35, pp. 937-45.

28. S.S. Sohn, S.Y. Han, S.Y. Shin, J. Bae, K. Kim, N.J. Kim, H.S. Kim, and S. Lee: Mater. Int., 2012, vol. 18, pp. 597-606.
29. D. Hull and D.J. Bacon: Introduction to Dislocations, 5th ed., Elsevier Ltd., Amsterdam, 2011.

30. Y. Ohomori, H. Ohtani, and T. Kunitake: Met. Sci., 1974, vol. 8, pp. 357-66.

31. A.P. Green and B.B. Hundy: J. Mech. Phys. Solids, 1956, vol. 4, pp. $128-44$.

32. J.M. Alexander and T.J. Komoly: J. Mech. Phys. Solids, 1962, vol. 10 , pp. 265-75.

33. H. Couque, R.J. Asaro, J. Duffy, and S.H. Lee: Metall. Trans. A, 1988, vol. 19A, pp. 2179-2206.

34. S.Y. Shin, K. Oh, S. Lee, and N.J. Kim: Met. Mater. Int., 2011, vol. 17, pp. 29-40.

35. W.M. Garrison, Jr and A.L. Wojcieszynski: Mater. Sci. Eng., 2007, vol. 464, pp. 321-29.

36. S. Kim, S. Lee, Y.-R. Im, H.-C. Lee, S.-J. Kim, and J.H. Hong: Metall. Mater. Trans. A, 2004, vol. 35A, pp. 2027-37.

37. S. Lee, B.C. Kim, and D. Kwon: Metall. Trans. A, 1993, vol. 24A, pp. $1133-41$.

38. R.O. Ritchie, J.F. Knott, and J.R. Rice: J. Mech. Phys. Solids, 1973, vol. 21, pp. 395-410.

39. D. Horsley: Eng. Fract. Mech., 2003, vol. 70, pp. 547-52. 